\title{
An Assessment of Software Project Management Maturity in Mauritius
}

\author{
Aneerav Sukhoo, Andries Barnard, Mariki M. Eloff, \\ and John A. Van der Poll \\ University of South Africa, Pretoria, South Africa \\ aneeravsukhoo@yahoo.com barnaa@unisa.ac.za \\ eloffmm@unisa.ac.za vdpolia@unisa.ac.za
}

\begin{abstract}
It is sometimes very difficult for an organization to adopt a specific software project management methodology in a short space of time. It requires sufficient time, adequate financial support and skilled human resources in order to start with a comprehensive methodology. It is, however, often more appropriate to use a maturity model so as to progress from one maturity level to the next.

Assessment of the maturity level of an organization provides a good benchmark to rate the success of its operations. One such exercise was carried out in South Africa in 2003, and the overall average project management maturity was found to be 2.92 (Sonnekus \& Labuschagne, 2004) on a scale of 1 to 5 . The maturity level was found to be closely linked to the success rate of projects. In this paper we report on a similar exercise conducted in Mauritius regarding the maturity level of software development projects. The average maturity of software development companies in Mauritius can provide a useful indication of, among others, the current status of software project management with a view of bringing about improvement in this sector.

Given that Mauritian software development companies are making use of European/Western software project management methodologies, this study has been carried out and a preliminary attempt was made to also assess their ability to deal with factors related to cultural, social, economic and political situation within the local context. These factors, when incorporated into existing project management methodologies, can bridge the gap between developing and developed countries and also contribute towards the globalization of software project management.
\end{abstract}

Keywords: software project management, maturity level, Mauritius, project management methodology, developing country.

\section{Introduction}

IT professionals generally have a grasp of the success rate of software projects as compared to other types of projects. The CHAOS report is published regularly to show the percentage of, among others, successfully completed software projects in the USA. The Standish Group (2002)

Material published as part of this journal, either on-line or in print, is copyrighted by Informing Science. Permission to make digital or paper copy of part or all of these works for personal or classroom use is granted without fee provided that the copies are not made or distributed for profit or commercial advantage AND that copies 1) bear this notice in full and 2) give the full citation on the first page. It is permissible to abstract these works so long as credit is given. To copy in all other cases or to republish or to post on a server or to redistribute to lists requires specific permission from the publisher at Publisher@InformingScience.org reports that only $34 \%$ of projects were completed successfully.

It is sometimes very difficult for an organization to adopt a specific software project management methodology in a short space of time. It requires sufficient time, adequate financial support and skilled human re- 
sources in order to start with a comprehensive methodology. A maturity model can allow organizations to progress from one maturity level to the next at their own pace.

Basically, project management maturity, and software project management maturity in particular, is the progressive development of an enterprise-wide project management approach, methodology, strategy, and decision-making process (Project Management Experts, 2004). A number of maturity models has been developed to allow organizations to progress at their own pace and some of these models has been summarized by Schiltz (2003) and Sonnekus and Labuschagne (2004). In a survey carried out in some Swiss organizations, Schiltz (2003) showed that project management maturity could be associated with project success. Such a correlation was also demonstrated by Sonnekus and Labuschagne (2004). Therefore, in an attempt to achieve a higher rate of successfully completed projects, it is worthwhile to consider enhancement of the project maturity level.

Although not all companies use project management maturity models, it is possible to assess their maturity levels. One such framework was put forward by Kwak and Ibbs (2002). An assessment exercise was carried out by Sonnekus and Labuschagne (2004) in the South African context by means of distribution of a questionnaire to various stakeholders. These assessment methodologies provide useful information on the state of project management, particularly software project management, within a country with the intention of bringing about improvements. Furthermore, this survey by Sonnekus and Labuschagne (2004) together with the survey carried out by Schiltz (2003) showed that project management success is linked to a high project maturity level.

A similar exercise as the one conducted by Sonnekus and Labuschagne (2004) in South Africa, was carried out in Mauritius to determine its software project management maturity level. A statistical approach is adopted with respect to the data gathered. Although Mauritius is facing a shortage of skilled labor, various programs have been initiated (Website of Ministry of Information Technology and Telecommunications, 2004), for example:

- a computer proficiency program has been launched to allow the public to benefit from Information Technology (IT) courses at a nominal fee;

- a second university has been set up to offer IT degree courses;

- access to Internet is now provided in most post-offices on the island or in public places;

- a school IT program will be launched to prepare the young generation to master basic IT skills; and

- a loan scheme at a low interest rate has been launched to allow each family to purchase a computer.

A previous survey was conducted to evaluate the current status and use of software project management methodologies in Mauritius (Sukhoo, Barnard, Eloff \& Van der Poll, 2004a). This survey showed that necessary steps should be taken to increase the rate of software project success. Furthermore, a substantial number of Mauritian software companies indicated that they were not comfortable with methodologies developed and used exclusively by Western countries that did not account for the economic rationality and cultural differences and the need to cope with political and community demands on the projects' resources in a developing country environment (Sukhoo et al., 2004a). This view is also expressed by Muriithi and Crawford (2003) who argue that software project management concepts are not universally valid due to assumptions on human behavior and cultural difference. Turner (1993) also argues that software project management techniques of western origin are not straightforward procedures that can be learnt and implemented due to cross-cultural problems. 
This paper presents an analysis of a survey carried out during 2004 to determine the software project maturity level in the Mauritian context. This survey was conducted by means of a questionnaire based on the one prepared by Sonnekus and Labuschagne (2004). In order to deal with scenarios related to problems in the Mauritian software industry, the questionnaire designed by Sonnekus and Labuschagne (2004), were expanded on in order to capture some specificities of Mauritius. The motivation of the current survey is presented by an earlier survey (Sukhoo et al., 2004a), which showed that the success rate of projects leaves much room for improvement.

A study was also conducted to justify the need for a software project management methodology by emphasizing the importance of strengths and weaknesses inherent in software projects (Sukhoo, Barnard, Eloff \& Van der Poll, 2004b). These two studies form part of a larger initiative to develop a software project management methodology specific for Mauritius.

\section{Background on Software Project Management Methodologies}

Several project management methodologies are available for software development projects as well as for other types of projects. In the preparation of the questionnaire used for this survey, the Project Management Body of Knowledge $\left(\mathrm{PMBOK}^{\circledR}\right.$ (PMI, 1996)) as well as some project maturity models have been combined to ascertain the maturity level of software project management of organizations. The questionnaire used may be found in appendix B.

\section{PMBOK $^{\circledR}$}

PMBOK $^{\circledR}$, developed by the Project Management Institute (PMI), is used globally (PMI, 1996) and the current version was released in 2000 . The PMBOK ${ }^{\circledR}$ methodology comprises 9 knowledge areas grouped into core functions and facilitating functions as in Figure 1. Each knowledge area is further divided into a number of processes. The total number of processes amounts to 39 . These processes are further mapped onto 5 process groups namely initiating, planning, executing, controlling and closing.

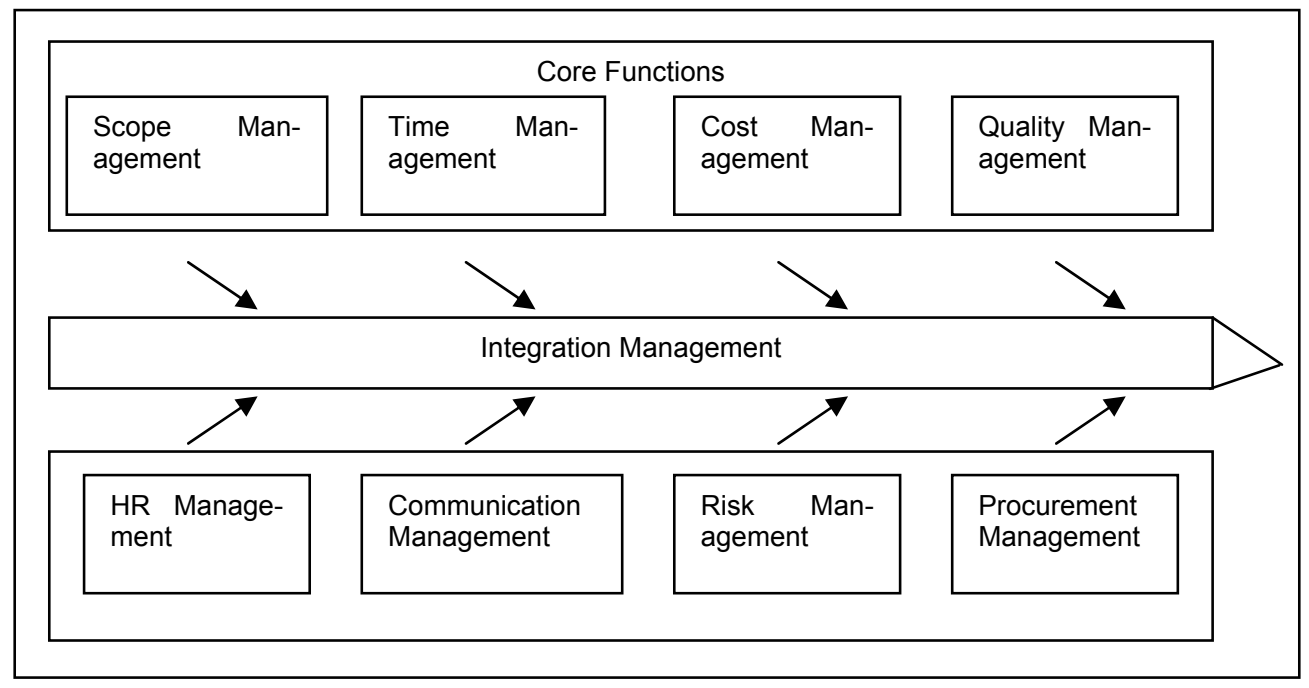

Figure 1: PMBOK® Guide

\section{Project Management Maturity Model (PMMM)}

Various PMMMs have been developed (e.g. MicroFrame self-assessment tools as described in Appendix A; Project Management Process Maturity (PM) ${ }^{2}$ as described in Appendix A; Kerzner's 
maturity model, as described in Appendix A; and SEI's Capability Maturity Model) and most of them are defined by five maturity levels, 1 through 5 (Schiltz, 2003; Sonnekus \& Labuschagne, 2004) as shown in Figure 2.

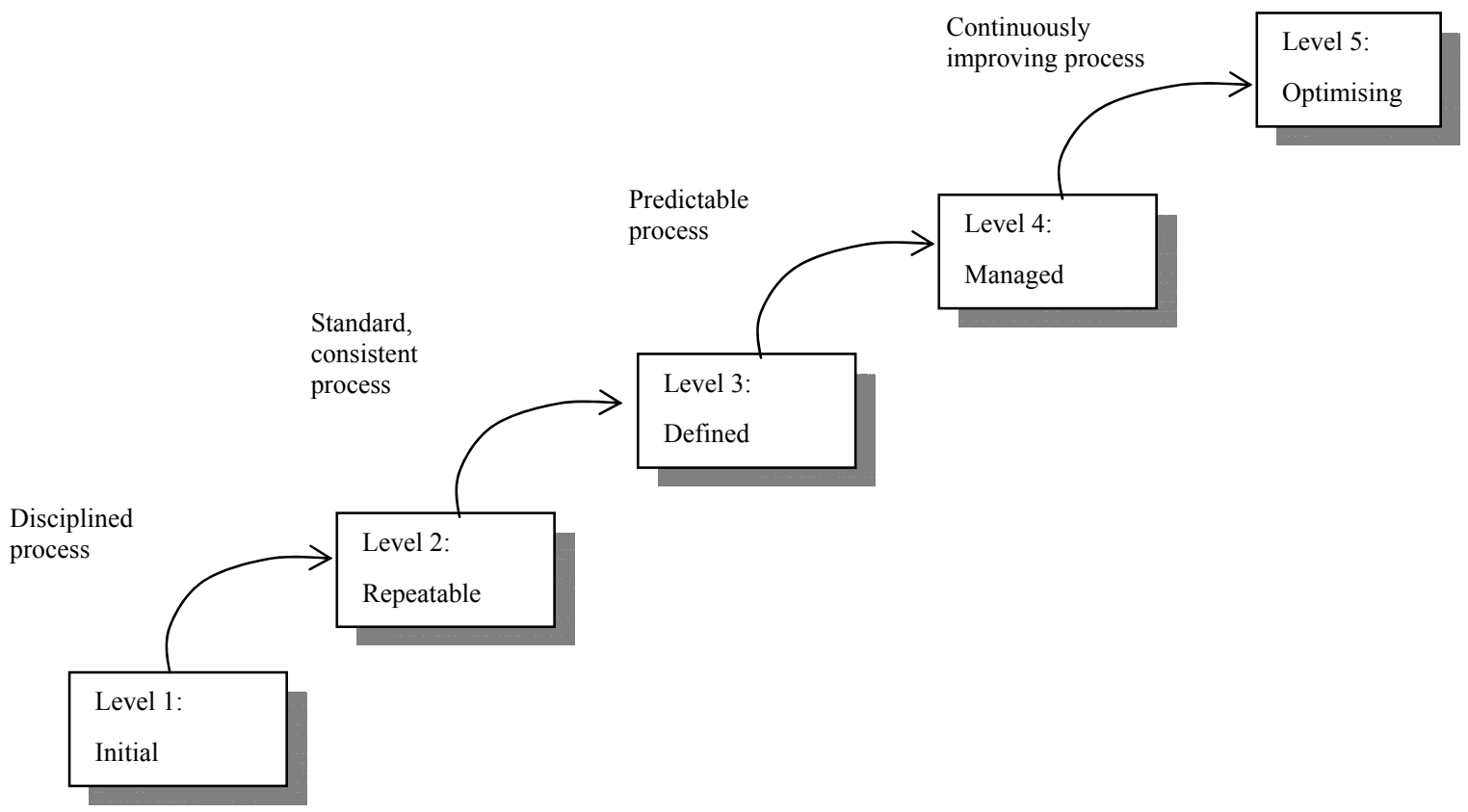

Figure 2: Five levels of maturity model (Paulk, Curtis, Chrissis, \& Weber, 1993)

Level 1 - Initial level

The software process is ad-hoc and occasionally chaotic. The success of projects depends on the skills of the project members.

Level 2 - Repeatable level

Processes are repeatable across projects. Basic project management processes are used to keep track of cost, schedule and quality.

Level 3 - Defined level

Project management processes are well established.

Level 4 - Managed level

Quantitative goals for both software products and processes are set by the organization.

Level 5 - Optimizing level

Lessons learnt and defects prevention are considered for continuous process improvement.

The Capability Maturity Model of SEI is a framework that describes the key elements of an effective software development process. The very thorough description of the framework makes it a strong theoretical starting point for developing process maturity models in other areas (such as project management). The process starts with maturity levels for which process capabilities are 
described. The question that is asked is: "What are the distinguishing capabilities that an organization has when it is at maturity level X?". By describing these capabilities, key process areas are identified, together with the goals that are attained using these process areas. In the next step, common features characterizing the successful implementation of these process areas are determined. Finally, key practices that indicate the successful implementation of the common features, i.e. infrastructure that is in place or activities that are performed, are described by Schiltz (2003) as per Figure 3 .

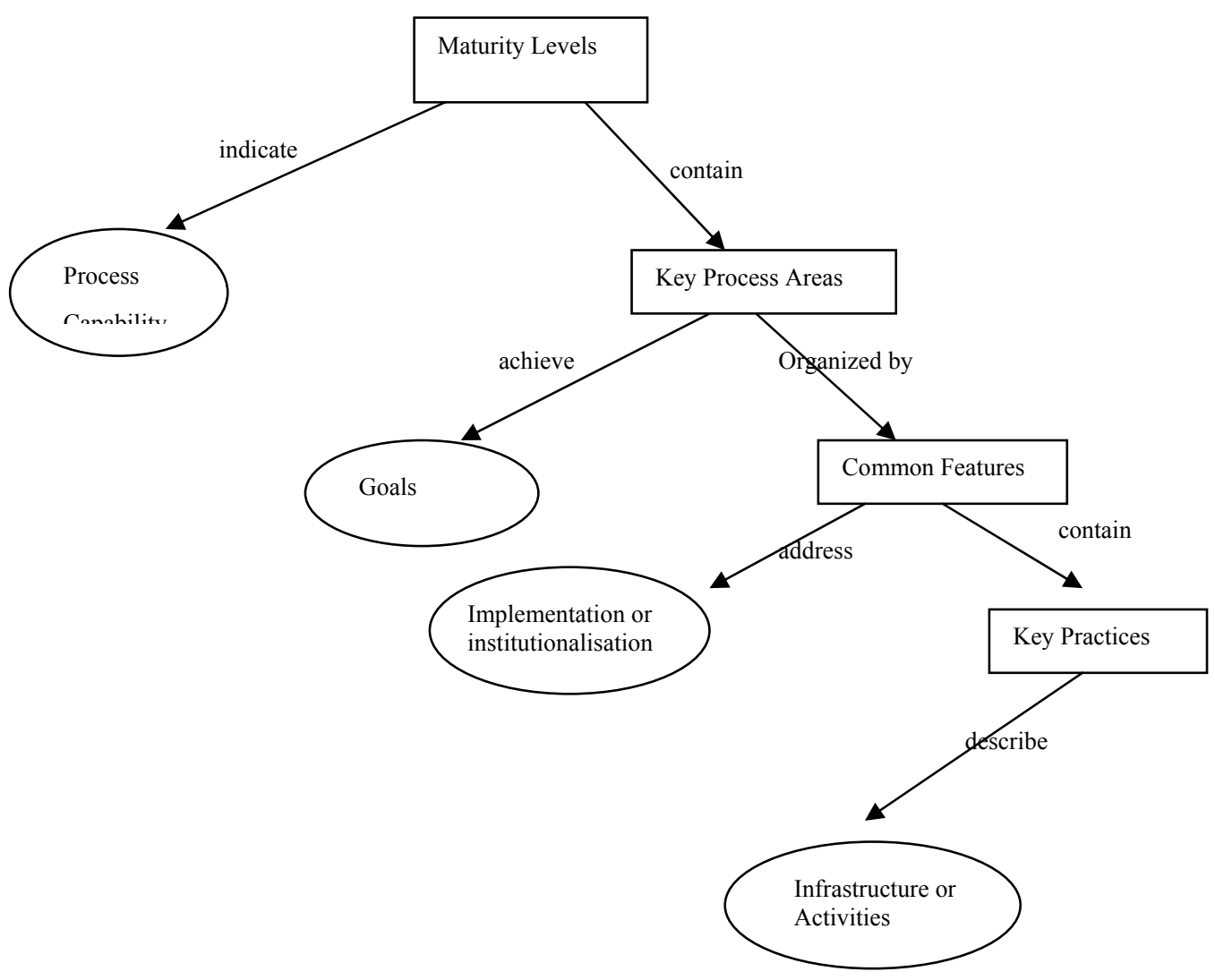

Figure 3: CMM derivation process (Schiltz, 2003)

\section{Research Methodology}

\section{Data Collection}

Data collection was carried out during 2004 by sending questionnaires via email to 65 companies and individuals actively involved in software development. The companies are those registered in Mauritius and they are listed on the Website of the National Computer Board in Mauritius (Website: http://ncb.intnet.mu). A total of 19 companies responded (i.e. 29\%) positively in spite of numerous phone calls made in order to increase the response rate. One of the main reasons identified for the low response rate is that representatives from the companies did not find time to fill in the questionnaire. The 19 respondents include small-sized through medium-sized to large-sized companies as well as some software developers in the IT Units of Ministries. An attempt was made to interview the persons concerned but it failed because these persons could not find the time to contribute to this research. 
As mentioned earlier in this paper, this questionnaire was based on work by Sonnekus and Labuschagne (2004). The first section of the questionnaire of Sonnekus and Labuschagne (2004) was adopted as is. Not all questions in the second section were considered. A third section was included to gather information related to economic, cultural and political implications specific to Mauritius.

\section{Analysis of Survey Data}

The data collected was input into a Microsoft Excel spreadsheet for analysis.

\section{Perceived Maturity Level versus Observed Maturity Level}

The mean values of data from the various companies were used to interpret the maturity levels as follows:

$$
\mathrm{M}_{\text {perceived }}=\underbrace{\mathbf{n}}_{\mathrm{i}=1} \mathrm{~L}_{\mathrm{i}}
$$

$\mathbf{n}$

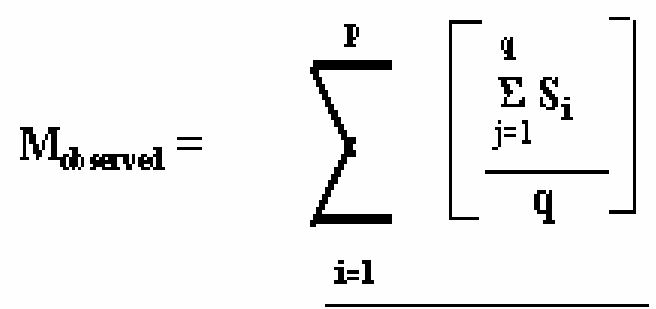

$\mathrm{L}=$ Perceived maturity level

$\mathrm{i}=\mathrm{i}^{\text {th }}$ company/individual

$\mathrm{n}=$ maximum number of responses received

$\mathrm{S}=$ process maturity level

$\mathrm{j}=\mathrm{j}^{\text {th }}$ process

$\mathrm{q}=$ maximum number of processes with maturity levels between 1 and 5 (i.e. excluding responses which are not applicable)

$\mathrm{p}=$ maximum number of processes considered.

The results are summarized in Table 1:

Table 1: Average maturity level

\begin{tabular}{|l|l|}
\hline Perceived maturity level & 2.26 \\
\hline Observed matily level & 2.29 \\
\hline
\end{tabular}

Observed maturity level

Difference

2.29
0.03
Self-assessment of the perceived maturity level is carried out by judging the appropriateness of the maturity level of an organization with respect to the applicable processes, documentation, management and metrics. Table 1 shows that there is a slight underestimation by companies/individuals in the assessment of maturity levels. 
From Table 1, it can be observed that Mauritian software development companies lie at an average maturity level of 2.29 and this possibly indicates an effort to achieve maturity level 3 . With the vision of the Government of Mauritius to transform the island into a Cyber Island and to develop Information and Communication Technologies (ICT) as the fifth pillar of the economy (Website of Ministry of Information Technology and Telecomunications, 2004), maturity level 3 appears to be an acceptable level for such ambitious initiatives. It is worth noting that the rapid development in the ICT sector has made people conscious of the use of project management methodologies in software development. Basic processes in the achievement of results are used and sufficiently documented. Basic metrics to track cost, schedule and quality are also used to prevent projects getting out of control and leading to project failures. This is in all probability a good sign for an emerging economy.

\section{Observed Maturity Level by Knowledge Area}

The maturity level of each process is evaluated and the average results are summarized in Table 2:

Table 2: Maturity levels by knowledge area

\begin{tabular}{|c|l|c|}
\hline \multicolumn{2}{|c|}{ Process Area } & Average maturity level \\
\hline \multicolumn{4}{|c|}{ Integration Management } & 2.28 \\
\hline \multirow{4}{*}{ Core Functions } & Scope Management & 2.46 \\
\cline { 2 - 3 } & Time Management & 2.34 \\
\cline { 2 - 3 } & Cost Management & 2.50 \\
\cline { 2 - 3 } & Quality Management & 2.35 \\
\hline \multirow{4}{*}{ Facilitating Functions } & 2.39 \\
\hline & Average for Core Functions & 2.29 \\
\cline { 2 - 3 } & Human Resource Management & 2.25 \\
\cline { 2 - 3 } & Communications Management & 1.84 \\
\cline { 2 - 3 } & Risk Management & 2.39 \\
\cline { 2 - 3 } & Procurement Management & 2.19 \\
\hline \multicolumn{2}{|c|}{ Average for Facilitating Functions } & \\
\hline
\end{tabular}

The above results can be depicted graphically in Figure 4:

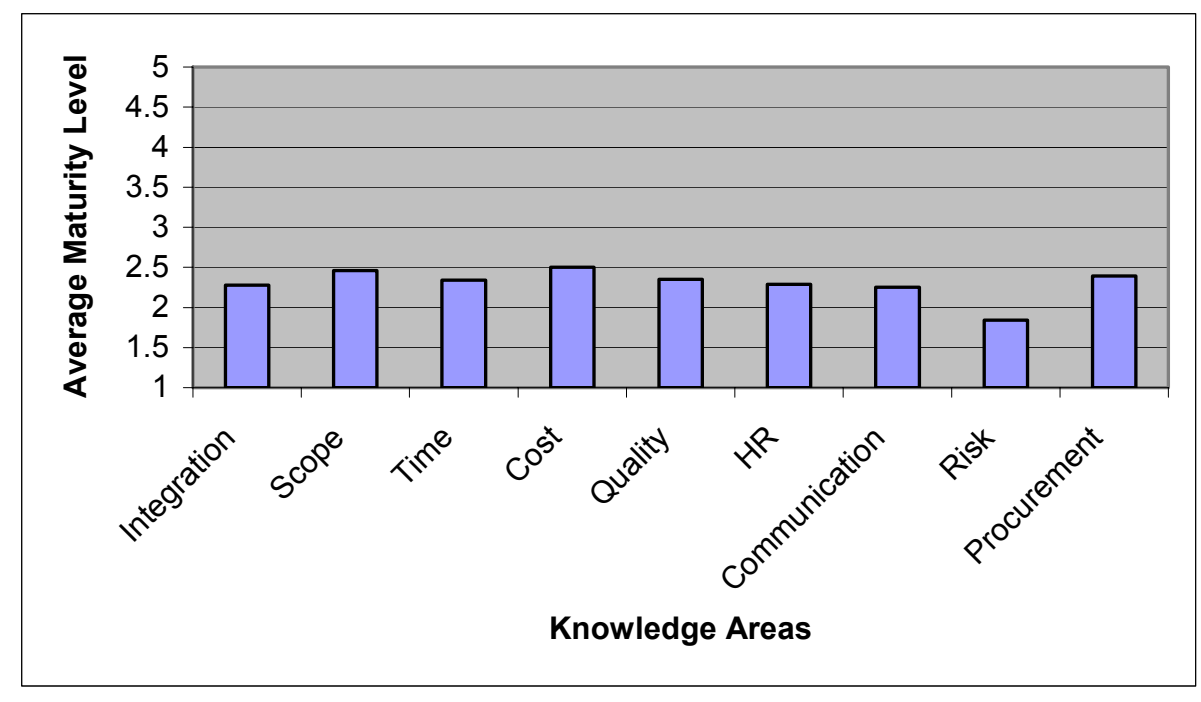

Figure 4: Average Maturity level by Knowledge Area 
Most of the knowledge areas score an average maturity level exceeding the value 2, except for Risk Management. This shows that Mauritian software developing companies need to pay more attention to risk management, which may be a major cause of software project failure.

Cost management has achieved the highest maturity level as compared to other knowledge areas. This is an indication that Mauritian software developing companies are quite concerned about cost overruns. Therefore, metrics to track cost of projects are given high importance.

Scope Management is equally treated with high priority given that this is a knowledge area that has to be considered at an early stage. An incorrectly formulated project scope will certainly have major impacts on subsequent phases of the project. Therefore, it is imperative to carefully determine the appropriate scope so as to minimize the risk of the project getting off track during later stages.

\section{Maturity Level by Process Groups}

Each knowledge area of $\mathrm{PMBOK}^{\circledR}$, considered in the previous section, is subdivided into a number of processes and these processes are mapped onto the following five process groups:

- initiating

- planning

- executing

- controlling

- closing

A further analysis of the data collected by virtue of the above process groups was carried out. The results are given in Table 3:

Table 3: Average maturity level by process group

\begin{tabular}{|c|c|c|c|c|c|}
\hline Knowledge areas and processes & Initiating & Planning I & Executing & Controlling & Closing \\
\hline \multicolumn{6}{|l|}{ Integration Management } \\
\hline Plan Development & & 2.33 & & & \\
\hline Plan Execution & & & 2.33 & & \\
\hline Integrated Change Control & & & & 2.17 & \\
\hline \multicolumn{6}{|l|}{ Scope Management } \\
\hline Initiation & 2.67 & & & & \\
\hline Scope Planning & & 2.39 & & & \\
\hline Scope Definition & & 2.44 & & & \\
\hline Scope Verification & & & & 2.56 & \\
\hline Scope Change Control & & & & 2.22 & \\
\hline \multicolumn{6}{|l|}{ Time Management } \\
\hline Activity Definition & & 2.32 & & & \\
\hline Activity Sequencing & & 2.35 & & & \\
\hline Activity Duration Estimating & & 2.47 & & & \\
\hline Schedule Development & & 2.44 & & & \\
\hline Schedule Control & & & & 2.12 & \\
\hline \multicolumn{6}{|l|}{ Cost Management } \\
\hline Resource Planning & & 2.65 & & & \\
\hline Cost Estimating & & 2.59 & & & \\
\hline Cost Budgeting & & 2.53 & & & \\
\hline Cost Control & & & & 2.25 & \\
\hline
\end{tabular}




\begin{tabular}{|c|c|c|c|c|c|}
\hline Knowledge areas and processes & Initiating & Planning & Executing & Controlling & Closing \\
\hline \multicolumn{6}{|l|}{ Quality Management } \\
\hline Quality Planning & & 2.25 & & & \\
\hline Quality Assurance & & & 2.4 & & \\
\hline Quality Control & & & & 2.4 & \\
\hline \multicolumn{6}{|l|}{ Human Resource Management } \\
\hline Organizational Planning & & 2.11 & & & \\
\hline Staff Acquisition & & 2.44 & & & \\
\hline Team Development & & & 2.31 & & \\
\hline \multicolumn{6}{|l|}{ Communications Management } \\
\hline Communications Planning & & 2.33 & & & \\
\hline Information Distribution & & & 2.17 & & \\
\hline Performance Reporting & & & & 2.21 & \\
\hline Administrative Closure & & & & & 2.29 \\
\hline \multicolumn{6}{|l|}{ Risk Management } \\
\hline Risk Management Planning & & 1.92 & & & \\
\hline Risk Identification & & 2.00 & & & \\
\hline Qualitative Risk Analysis & & 1.69 & & & \\
\hline Quantitative Risk Analysis & & 1.69 & & & \\
\hline Risk Response Planning & & 1.92 & & & \\
\hline Risk Monitoring and Control & & & & 1.83 & \\
\hline \multicolumn{6}{|l|}{ Procurement Management } \\
\hline Procurement Planning & & 2.33 & & & \\
\hline Solicitation Planning & & 2.28 & & & \\
\hline Solicitation & & & 2.44 & & \\
\hline Source Selection & & & 2.33 & & \\
\hline Contract Administration & & & & 2.47 & \\
\hline Contract Closeout & & & & & 2.5 \\
\hline Average for each process group & 2.67 & 2.26 & 2.33 & 2.25 & 2.40 \\
\hline
\end{tabular}

\section{Maturity Level to Cope with Factors such as Culture, Politics, Climate, Economy, etc.}

The perceived maturity level versus observed maturity level to cope with other factors like culture, politics, climate, economy, etc. are summarized in Table 4:

Given that Mauritian software development companies are making use of project management methodologies based on European/Western countries, this study has been carried out to assess their ability to deal with factors within the local context. The results in the above table show an average maturity level of 2.12 , while an underestimated

\begin{tabular}{|l|l|}
\hline \multicolumn{2}{|l|}{ Table 4: Average maturity level } \\
\hline Perceived maturity level & 1.95 \\
\hline Observed maturity level & 2.12 \\
\hline Difference & 0.17 \\
\hline
\end{tabular}
value of 1.95 is generally perceived.

There is an indication that companies are aware that these factors have to be taken, consciously or unconsciously, into consideration while managing software projects. These factors have to be incorporated into project management methodologies through a careful study. This research can possibly bridge the gap that exists between developing and developed countries in the field of software project management. The observed maturity level also shows a possible effort to achieve a higher maturity level. Given that popular software project management methodologies like 
PRINCE2 (PRINCE2, 2004), PMBOK ${ }^{\circledR}$ (PMI, 2000), SEI's Capability Maturity Model (CMM Online, 2004), that are widely used are not universally applicable (Muriithi \& Crawford, 2003). Mauritian software development companies have had to adjust to the local situation. There is a need to enhance further the means to cope with relevant factors that may affect software projects in Mauritius. Achievement of higher maturity levels in this area may very well bridge the gap that exists between developing countries and Western/European countries. Given that attempts are being made for the globalization of software project management methodologies, it is anticipated that this venture will be worthwhile. In this way, developing economies like that of Mauritius, will remain current.

\section{Conclusion}

The maturity level of an organization provides a benchmark for the success of its operation. Sonnekus and Labuschagne (2004) showed the link between maturity level and success rate in software projects undertaken in South Africa by means of a survey conducted. A similar survey conducted in Mauritius revealed the maturity level of software development organizations by knowledge area, process and process group. The results obtained are quite encouraging for Mauritius as a developing country. It shows that the island is making a concerted effort to progress in the software development field. The average maturity level already exceeds level 2 (average maturity of 2.29) and there is a trend to reach the next level given that Mauritius is attracting well-established Indian Companies like Satyam Computers Services Ltd and Infosys Technologies Ltd amongst others.

According to Schiltz (2003) and Sonnekus and Labuschagne (2004), a link exists between project management maturity and project success. We conclude by noting that the current survey together with the previous one supports the need for a methodology that can bridge the existing gap in software project management between Mauritius (or possibly other developing countries) and developed countries in an attempt to globalize the discipline.

\section{References}

CMM Online. (2004). The Capability Maturity Model for Software ${ }^{\circledR}(\mathrm{SW}-\mathrm{CMM} \circledR)$. Retrieved June 15, 2004, from http://www.teraquest.com/cmmOnline/Summary_Ls.html

Kwak, Y. H., \& Ibbs, C. W. (2002). Project management process maturity (PM) ${ }^{2}$ Model. Journal of Management in Engineering, 18(3), 150-155.

Muriithi, N., \& Crawford, L. (2003). Approaches to project management in Africa: Implications for international development projects. International Journal of Project Management, 21(5), 309-319.

Paulk, M. C., Curtis, B., Chrissis, M. B., \& Weber, C. V. (1993). Capability maturity model for software, version 1.1. Retrieved October 14, 2004, from http://www.sei.cmu.edu/pub/documents/93.reports/pdf/tr24.93.pdf

PMI (1996). A guide to the project management body of knowledge. PMI, USA.

PRINCE2 (2003). Retrieved November 19, 2004, from http://www.teraquest.com/cmmOnline/Summary Ls.html

Project Management Experts, PM Solutions (2004). What is project management maturity? Retrieved July 27, 2004, from http://www.pmsolution.com/maturitymodel/whatispmm.htm

Schiltz, S. J. (2003). A practical method for assessing the financial benefit of project management. Master of Science thesis. City University. Retrieved May 19, 2004, from http://www.pmiswitzerland.ch/knowledge/costofbadpm_schiltz_v11.pdf 
Sonnekus, R., \& Labuschagne, L. (2004). Establishing the relationship between IT project management maturity and IT project success in a South African context. Proceedings of the 2004 PMSA Global Knowledge Conference, Johannesburg, South Africa, 183-192.

Sukhoo, A., Barnard, A., Eloff, M.M., \& Van der Poll, J.A. (2004a). A survey of project management tools, techniques and methodologies used in Mauritius: The current status. Proceedings of the 2004 PMSA Global Knowledge Conference, Johannesburg, South Africa, 320-329.

Sukhoo, A., Barnard, A., Eloff, M.M., \& Van der Poll, J.A. (2004b). Towards a framework for evaluating strengths and weaknesses of software projects. Proceedings of the 2004 PMSA Global Knowledge Conference, Johannesburg, South Africa, 193-199.

The Standish Group (2002). CHAOS Report as cited by Sonnekus, R., \& Labuschagne, L. (2004). Establishing the relationship between IT project management maturity and IT project success in a South African context. Proceedings of the 2004 PMSA Global Knowledge Conference, Johannesburg, South Africa, 183-192.

Turner, J.R. (1993). The handbook of project-based management: Improving the processes of achieving strategic objectives. London: McGraw-Hill.

Website of Ministry of Information Technology and Telecommunications (2004). Retrieved November 19, 2004, from http://telecomit.gov.mu

\section{Appendix A - Maturity Models}

The maturity models described below are as presented by Schiltz (2003).

\section{MicroFrame's Self Assessment Tool}

Microframe Technologies, together with Project Management Technologies, have developed and made available on the Internet a self-assessment tool for project management maturity with 50 multiple-choice questions (Enterprise Planning Associates, 2000). The result of this quick selfassessment is a ranking in one of the following five categories:

Level 1 - Ad-hoc: The project management process is described as disorganized, and occasionally even chaotic. Systems and data processes are not defined. Project success depends on individual effort. Chronic cost and schedule problems.

Level 2 - Abbreviated: Some project management processes and systems are established to track cost, schedule, and performance. Underlying disciplines, however, are not well understood or consistently followed. Project success is largely unpredictable and cost and schedule problems are the norm.

Level 3 - Organized: Project management processes and systems are documented, standardized, and integrated into an end-to-end process for the company. Project success is more predictable. Cost and schedule performance is improved.

Level 4 - Managed: Detailed measures of the effectiveness of project management are collected and used by management. The process is understood and controlled. Project success is more uniform. Cost and schedule performance conforms to plan.

Level 5 - Adaptive: Continuous improvement of the project management process is enabled by feedback from the process and from piloting innovative ideas and technologies. Project success is the norm. Cost and schedule performance is continuously improving.

\section{(PM) ${ }^{2}$ Maturity Assessment Methodology}

A research team formed by Professor William C. Ibbs at the University of California at Berkeley set itself the goal to investigate the financial and organizational benefits to organizations that re- 
sult from the implementation of project management processes. One of their research steps was to develop a five-level "Project Management Process Maturity" (PM) ${ }^{2}$ model (see figure below) that would allow them to collect and compare project management process information for a number of organizations to be used in further research studies. The five levels of maturity are described as follows:

Level 1 - Ad-hoc Stage: Organizations at level 1 do not use formal procedures for executing a project. Project activities are poorly defined and cost estimates are inferior.

Level 2 - Planned Stage: At the planned stage, informal and incomplete procedures manage a project. The organization has a strength in doing similar and repeatable work.

Level 3 - Managed Stage: Most of the project management problems are identified and informally documented. PM data for project planning and management are collected across the organization.

Level 4 - Integrated Stage: At the integrated stage, an organization can manage, integrate, and control multiple projects efficiently. PM process data are standardized, collected, and stored.

Level 5 - Sustained Stage: At the sustained stage, PM processes are continuously improved. PM data are collected and rigorously analyzed to improve processes. Innovative ideas are vigorously pursued.

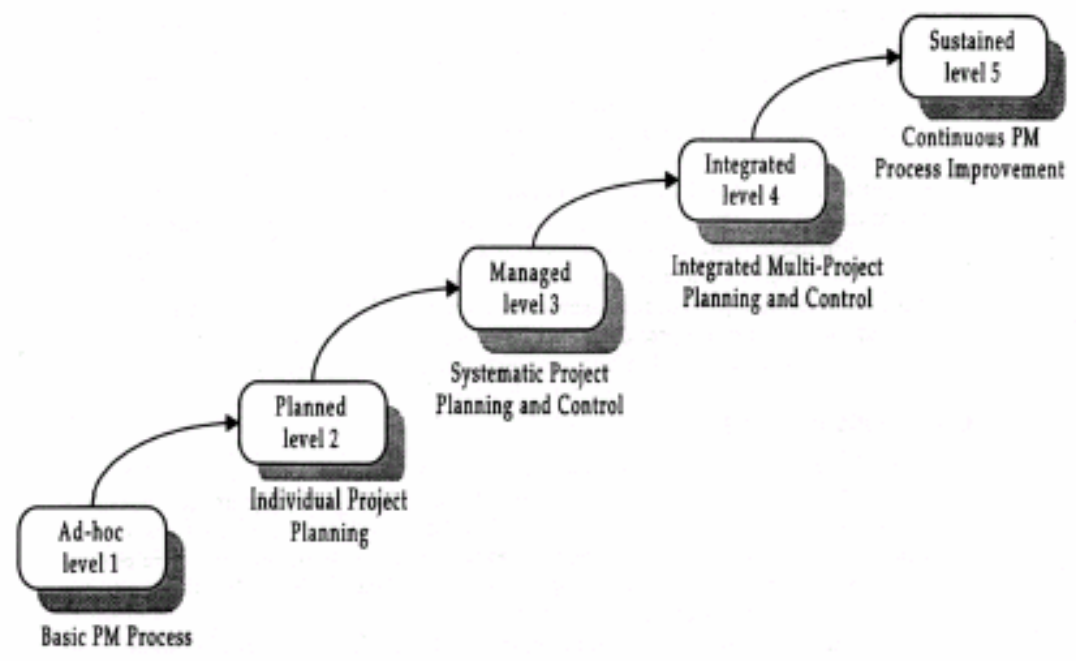

Figure 5: Five levels of (PM) ${ }^{2}$ (Schiltz, 2003)

\section{Kerzner's Project Management Maturity Model}

Harold Kerzner and the International Institute for Learning (IIL) view project management as a core competency that many companies must develop in order to remain competitive in the market. In this context, project management maturity models are important strategic tools for senior management allowing an organization to benchmark its capabilities in respect of project management. As such, a project management maturity assessment model is a tool for establishing project management excellence, which is considered a condition for success.

Like $(\mathrm{PM})^{2}$ and CMM, Kerzner's maturity model defines five levels by which an organization is ranked from insufficient project management processes to adequate project management processes leading to continuous improvement. These five levels are shown in the figure below and are described as follows: 
Level 1 - Common Language: The organization recognizes the importance of project management and the need for a good understanding of the basic knowledge on project management.

Level 2 -Common Processes: At his level, the organization recognizes that common processes need to be defined and developed so that project success can be repeated.

Level 3 - Singular Methodology: The organization defines a single methodology for project management in order to take advantage of the associated synergistic effect.

Level 4 -Benchmarking: The organization recognizes that process improvement is necessary to maintain competitive advantage.

Level 5 - Continuous Improvement: At this level, the organization evaluates the information obtained through benchmarking and decides how to improve its processes.

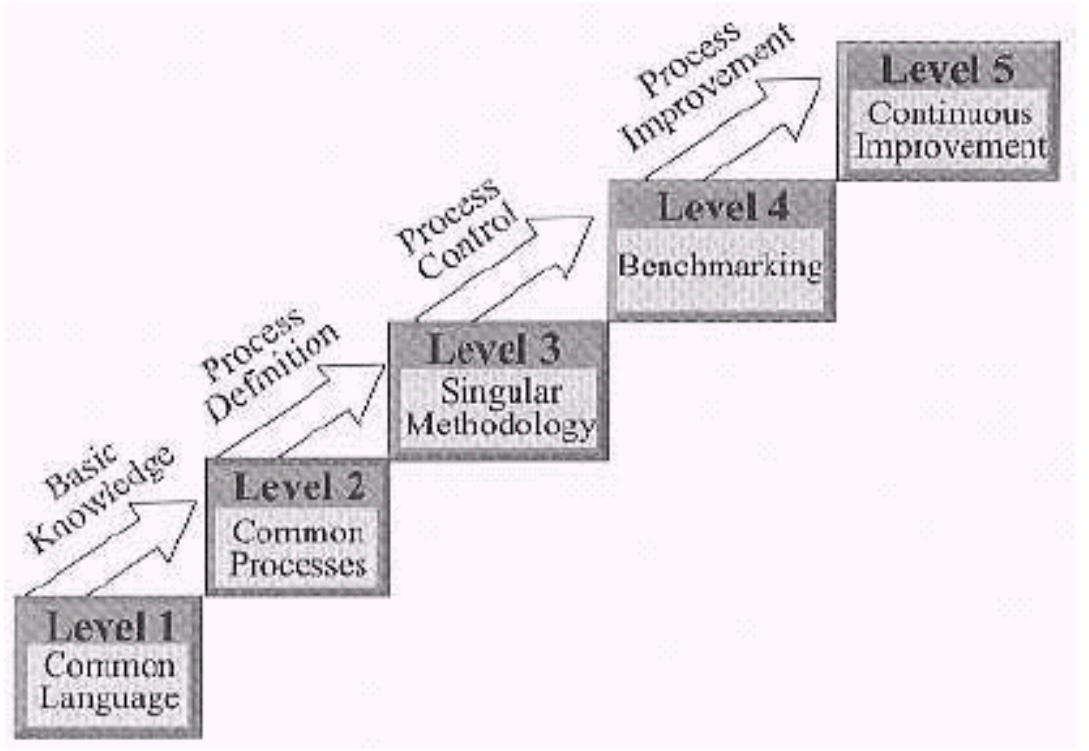

Figure 6: Kerzner's maturity levels (Schiltz, 2003)

\section{Appendix B - Questionnaire Project Management Survey - Maturity vs Project Success Definitions}

Please consider the following definitions carefully before completing the questionnaire. The following definitions are referred to the maturity levels in questions in section A and B.

\section{Maturity Level 1 - Initial Process}

- Processes - No established practices and standards.

- Documentation - Loose and ad-hoc.

- Management - Management understands the definition of a project, and is aware of the need for project management.

- Metrics - Collected informally on an ad-hoc basis. 


\section{Maturity Level 2 - Structured Process and Standards}

- Processes - Processes exist, but are not considered an organizational standard.

- Documentation - Documentation exists on the basic processes.

- Management - Management supports the implementation of project management, but understanding and involvement is not consistent / applied to all projects. Large projects are executed in a systematic fashion, and management is involved in such projects.

- Metrics - Basic metrics to track cost, schedule and technical performance exist.

\section{Maturity Level 3 - Organizational Standards and Institutionalized Process}

- Processes - All project management processes are in place and established as organizational standards. These processes involve the clients as members of the project team. Nearly all projects use these processes.

- Documentation - Documentation exists on all the processes.

- Management - Management is regularly involved in input and approval of key decisions.

- Metrics - Metrics are formally collected and each project is evaluated and managed in light of other projects.

\section{Maturity Level 4 - Managed Process}

- Processes - project management processes, standards and supporting systems are integrated with other corporate processes and systems.

- Documentation - Processes and standards are documented to support using metrics to make project decisions.

- Management - Management understands its role in the project management process. There are different management styles and project management requirements for different projects.

- Metrics - Efficiency and effectiveness metrics are used. All projects, changes and issues are evaluated based upon metrics from cost estimates, baseline estimates, and earned value calculations.

\section{Maturity Level 5 - Optimizing Process}

- Processes - Processes are in place and actively used to improve project management activities.

- Documentation - Lessons learned are regularly examined and used to improve project management processes, standards and documentation.

- Management - Management is focused not only on effectively managing projects but also on continuous improvement.

- Metrics - The metrics collected during project execution are used to understand the performance of a project and to assist in the making of organizational management decisions for the future. 


\section{Section A \\ Project Management Maturity}

Please rate each of the following statements according to the maturity levels on the previous page, by making an $\mathbf{X}$ in the appropriate box. If your organization does not implement a specific section, please mark the N/A (not applicable) box.

\begin{tabular}{|l|l|l|l|l|l|}
\hline 1. Overall Level of Maturity & $\mathbf{1}$ & $\mathbf{2}$ & $\mathbf{3}$ & $\mathbf{4}$ & $\mathbf{5}$ \\
\hline $\begin{array}{l}\text { a. What do you think the overall level of project management maturity is } \\
\text { in your organization? }\end{array}$ & & & & \\
\hline
\end{tabular}

\begin{tabular}{|c|c|c|c|c|c|c|}
\hline 2. Project Integration Management & N/A & 1 & 2 & 3 & 4 & 5 \\
\hline $\begin{array}{l}\text { a. Project Plan Development } \\
\text { Integrating and coordinating all project plans to create a consis- } \\
\text { tent, coherent document. }\end{array}$ & & & & & & \\
\hline $\begin{array}{l}\text { b. Project Plan Execution } \\
\text { Executing the project plan by performing the activities included } \\
\text { therein. }\end{array}$ & & & & & & \\
\hline $\begin{array}{l}\text { c. Integrated Change Control } \\
\text { Coordinating changes across the entire project. }\end{array}$ & & & & & & \\
\hline
\end{tabular}

\begin{tabular}{|c|c|c|c|c|c|c|}
\hline 3. $\quad$ Project Scope Management & $\mathbf{N} / \mathbf{A}$ & 1 & 2 & 3 & 4 & 5 \\
\hline $\begin{array}{l}\text { a. Initiation } \\
\text { Authorizing the project or phase. }\end{array}$ & & & & & & \\
\hline $\begin{array}{l}\text { b. Scope Planning } \\
\text { Developing a written scope statement as the basis for future } \\
\text { project decisions. }\end{array}$ & & & & & & \\
\hline $\begin{array}{l}\text { c. Scope Definition } \\
\text { Subdividing the major project deliverables into smaller, more } \\
\text { manageable components. }\end{array}$ & & & & & & \\
\hline $\begin{array}{l}\text { d. Scope Verification } \\
\text { Formalizing acceptance of the project scope. }\end{array}$ & & & & & & \\
\hline $\begin{array}{l}\text { e. Scope Change Control } \\
\text { Controlling changes to project scope. }\end{array}$ & & & & & & \\
\hline
\end{tabular}

\begin{tabular}{|c|c|c|c|c|c|c|}
\hline Project Time Management & $\mathbf{N} / \mathbf{A}$ & 1 & 2 & 3 & 4 & 5 \\
\hline $\begin{array}{l}\text { a. Activity Definition } \\
\text { Identifying the specific activities that must be performed to } \\
\text { produce various project deliverables. }\end{array}$ & & & & & & \\
\hline $\begin{array}{l}\text { b. Activity Sequencing } \\
\text { Identifying and documenting interactivity dependencies. }\end{array}$ & & & & & & \\
\hline $\begin{array}{l}\text { c. Activity Duration Estimating } \\
\text { Estimating the number of work periods that will be required to } \\
\text { complete individual activities. }\end{array}$ & & & & & & \\
\hline $\begin{array}{l}\text { d. Schedule Development } \\
\text { Analyzing activity sequences, activity durations and resource }\end{array}$ & & & & & & \\
\hline
\end{tabular}




\begin{tabular}{|l|l|l|l|l|l|}
\hline requirements to create the project schedule. & & & & & \\
\hline e. Schedule Control \\
Controlling changes to the project schedule.
\end{tabular}

\begin{tabular}{|c|c|c|c|c|c|c|}
\hline Project Cost Management & N/A & 1 & 2 & 3 & 4 & 5 \\
\hline $\begin{array}{l}\text { a. Resource Planning } \\
\text { Determining what resources and what quantities of each should } \\
\text { be used to perform project activities. }\end{array}$ & & & & & & \\
\hline $\begin{array}{l}\text { b. Cost Estimating } \\
\text { Developing an estimate of the costs of the resources required to } \\
\text { complete project activities. }\end{array}$ & & & & & & \\
\hline $\begin{array}{l}\text { c. Cost Budgeting } \\
\text { Allocating the overall cost estimate to individual work activi- } \\
\text { ties. }\end{array}$ & & & & & & \\
\hline $\begin{array}{l}\text { d. Cost Control } \\
\text { Controlling changes to the project budget. }\end{array}$ & & & & & & \\
\hline
\end{tabular}

\begin{tabular}{|c|c|c|c|c|c|c|}
\hline Project Quality Management & $\mathbf{N} / \mathbf{A}$ & 1 & 2 & 3 & 4 & 5 \\
\hline $\begin{array}{l}\text { a. Quality Planning } \\
\text { Identifying which quality standards are relevant to the project } \\
\text { and determining how to satisfy them. }\end{array}$ & & & & & & \\
\hline $\begin{array}{l}\text { b. Quality Assurance } \\
\text { Evaluating overall project performance on a regular basis to } \\
\text { provide confidence that the project will satisfy the relevant } \\
\text { quality standards. }\end{array}$ & & & & & & \\
\hline $\begin{array}{l}\text { c. Quality Control } \\
\text { Monitoring specific project results to determine if they comply } \\
\text { with relevant quality standards and identifying ways to elimi- } \\
\text { nate causes of unsatisfactory performance. }\end{array}$ & & & & & & \\
\hline
\end{tabular}

\begin{tabular}{|c|c|c|c|c|c|c|}
\hline 7. Project Human Resource Management & $\mathbf{N} / \mathbf{A}$ & 1 & 2 & 3 & 4 & 5 \\
\hline $\begin{array}{l}\text { a. Organizational Planning } \\
\text { Identifying, documenting and assigning project roles, responsi- } \\
\text { bilities and reporting relationships. }\end{array}$ & & & & & & \\
\hline $\begin{array}{l}\text { b. Staff Acquisition } \\
\text { Procuring the required human resources and assigning it to the } \\
\text { project. }\end{array}$ & & & & & & \\
\hline $\begin{array}{l}\text { c. Team Development } \\
\text { Developing individual and group competencies to enhance pro- } \\
\text { ject performance. }\end{array}$ & & & & & & \\
\hline
\end{tabular}

\begin{tabular}{|l|l|l|l|l|l|l|}
\hline 8. Project Communications Management & N/A & $\mathbf{1}$ & $\mathbf{2}$ & $\mathbf{3}$ & $\mathbf{4}$ & $\mathbf{5}$ \\
\hline $\begin{array}{l}\text { a. Communications Planning } \\
\text { Determining the information and communications needs of the } \\
\text { stakeholders. }\end{array}$ & & & & & & \\
\hline b. Information Distribution & & & & & \\
\hline
\end{tabular}




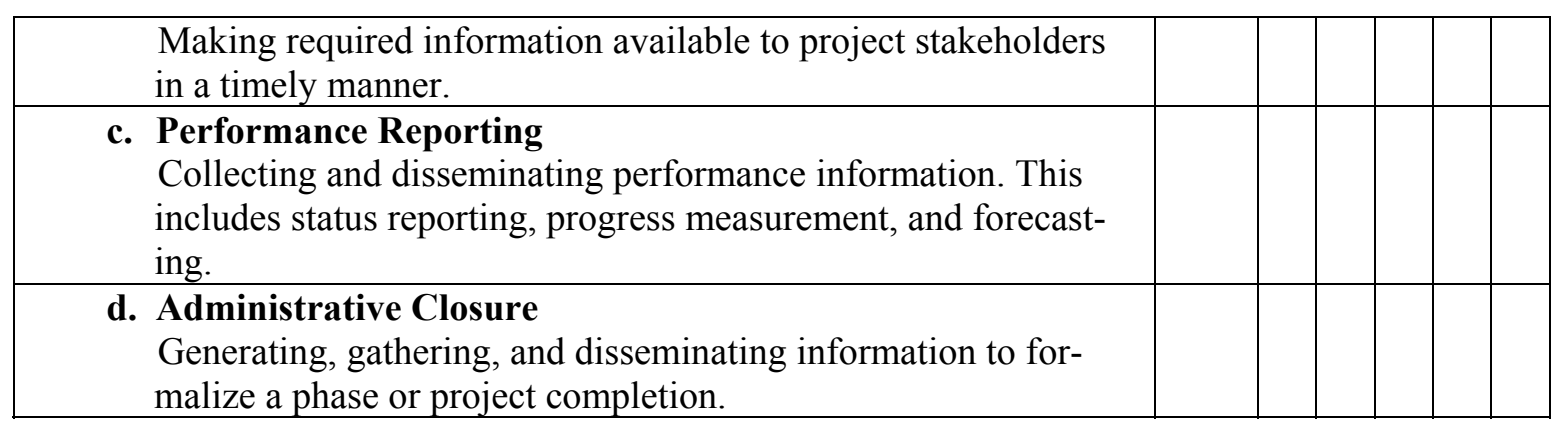

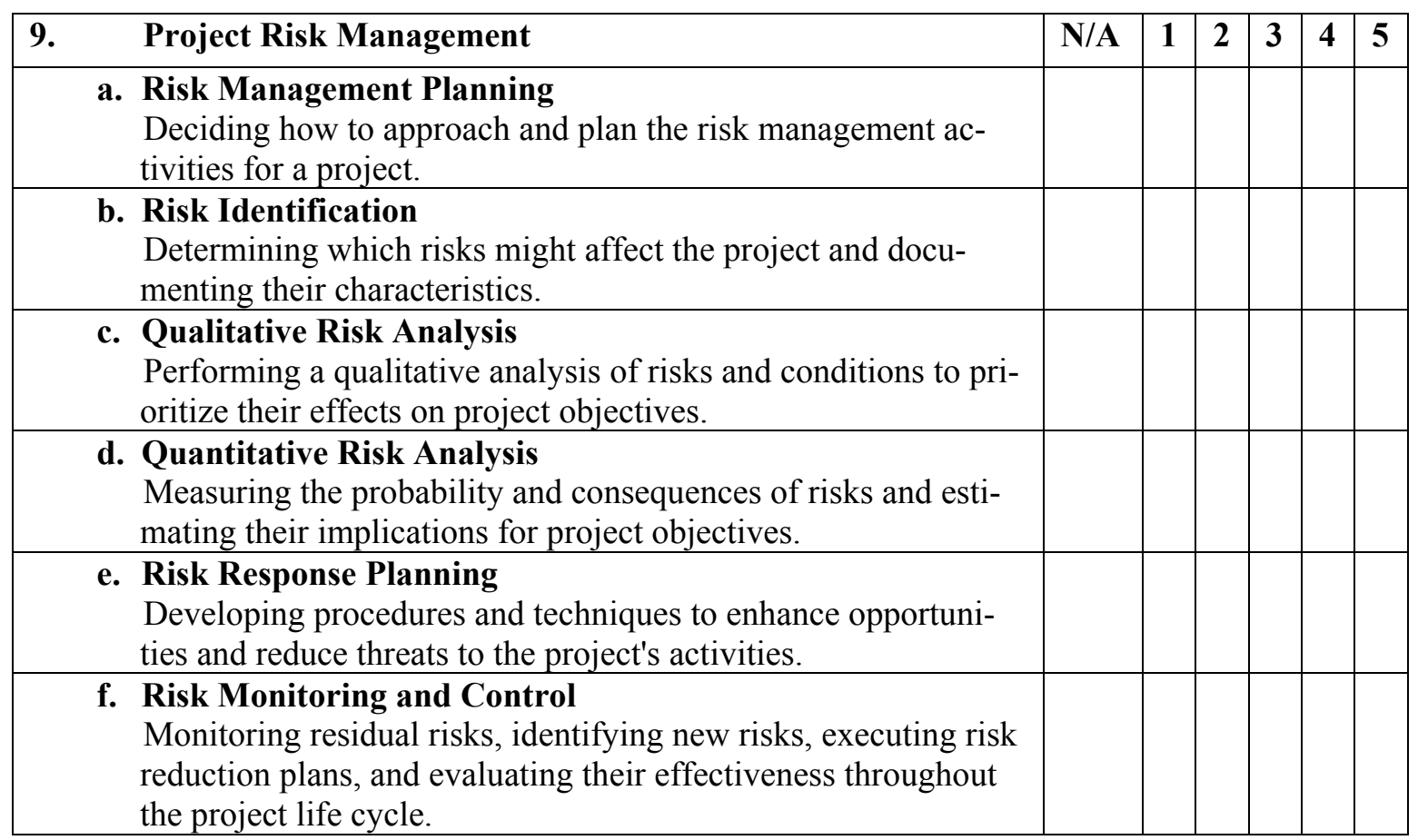

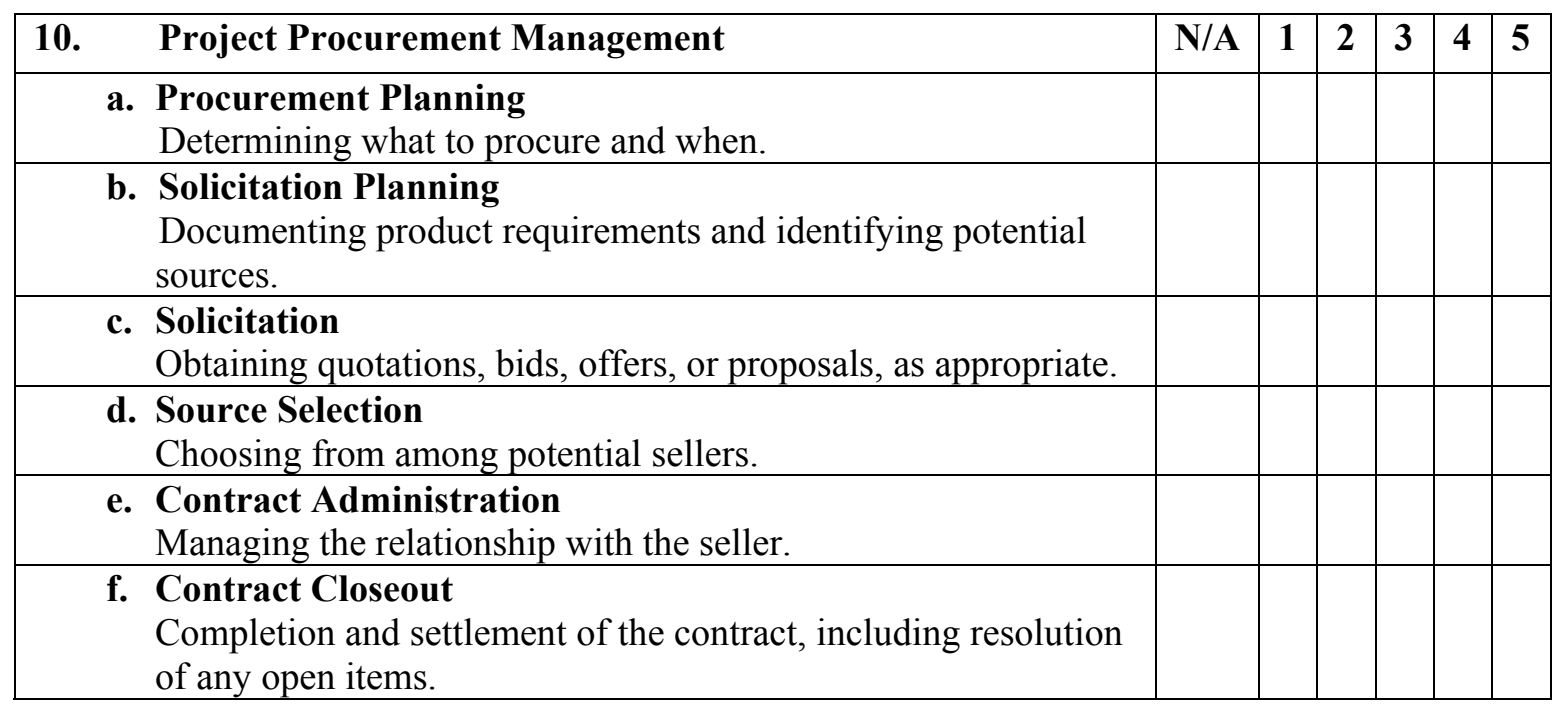




\section{Section B \\ Maturity to Cope with Other Factors}

\begin{tabular}{|c|c|c|c|c|c|}
\hline $\begin{array}{l}\text { 1. Overall Level of Maturity to cope with other Factors (e.g. cultural, } \\
\text { political, climatic and economic) }\end{array}$ & 1 & 2 & 3 & 4 & 5 \\
\hline $\begin{array}{l}\text { a. What do you think about the overall level of maturity to cope with fac- } \\
\text { tors like culture, politics, religion, infrastructure, bad climatic condi- } \\
\text { tions, etc. that affect projects in your organization? }\end{array}$ & & & & & \\
\hline
\end{tabular}

\begin{tabular}{|c|c|c|c|c|c|c|c|}
\hline 2. & Other aspects to be considered during Project Management & $\mathbf{N} / \mathbf{A}$ & 1 & 2 & 3 & 4 & 5 \\
\hline a. & $\begin{array}{l}\text { Organizational Culture } \\
\text { Existence of an organizational culture to keep project team in- } \\
\text { tegrated as a community to achieve corporate goal. }\end{array}$ & & & & & & \\
\hline b. & $\begin{array}{l}\text { Individualism/collectivism } \\
\text { Ability to cope with individualist/collectivist nature of staff. } \\
\text { (Individualistic nature: where ties with others, including fami- } \\
\text { lies, are loose and therefore staff may view that their work is } \\
\text { more important than others.) } \\
\text { (Collectivist nature: where ties with others, including families, } \\
\text { are strong and therefore others are viewed with greater values) }\end{array}$ & & & & & & \\
\hline c. & $\begin{array}{l}\text { Uncertainty avoidance } \\
\text { Coping with uncertainty avoidance. } \\
\text { (Uncertainty avoidance: The extent to which low risk taking } \\
\text { and emotional resistance to change are preferred) }\end{array}$ & & & & & & \\
\hline d. & $\begin{array}{l}\text { Gender equality } \\
\text { Ability to cope with gender issues and to treat both as equal } \\
\text { during recruitment or other circumstances. }\end{array}$ & & & & & & \\
\hline e. & $\begin{array}{l}\text { Authority } \\
\text { Managing authority so that decisions are not delayed. } \\
\text { (High authority represents a high acceptance by less powerful } \\
\text { individuals. It is often associated with taller organizational } \\
\text { structures and unwillingness to make decisions lower down } \\
\text { without reference to superiors) }\end{array}$ & & & & & & \\
\hline f. & $\begin{array}{l}\text { Religion } \\
\text { Ability to cope with religious dimension so that projects are not } \\
\text { affected. For instance, during certain religious festivals (like } \\
\text { Maha Shivratree, Eid, Easter, Spring festival, etc.), some em- } \\
\text { ployees may take some days of leave that may impact on pro- } \\
\text { jects. }\end{array}$ & & & & & & \\
\hline 5. & $\begin{array}{l}\text { Infrastructure } \\
\text { Ability to cope with infrastructure problems (e.g. transport, } \\
\text { education system, new technology, communications infrastruc- } \\
\text { ture, etc.) that may have impacts of projects. }\end{array}$ & & & & & & \\
\hline & $\begin{array}{l}\text { Climate } \\
\text { Ability to cope with delays due to natural calamities (like cy- } \\
\text { clone and heavy continuous rain). }\end{array}$ & & & & & & \\
\hline 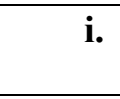 & $\begin{array}{l}\text { Politics } \\
\text { Ability to cope with politics that may have influence on the }\end{array}$ & & & & & & \\
\hline
\end{tabular}




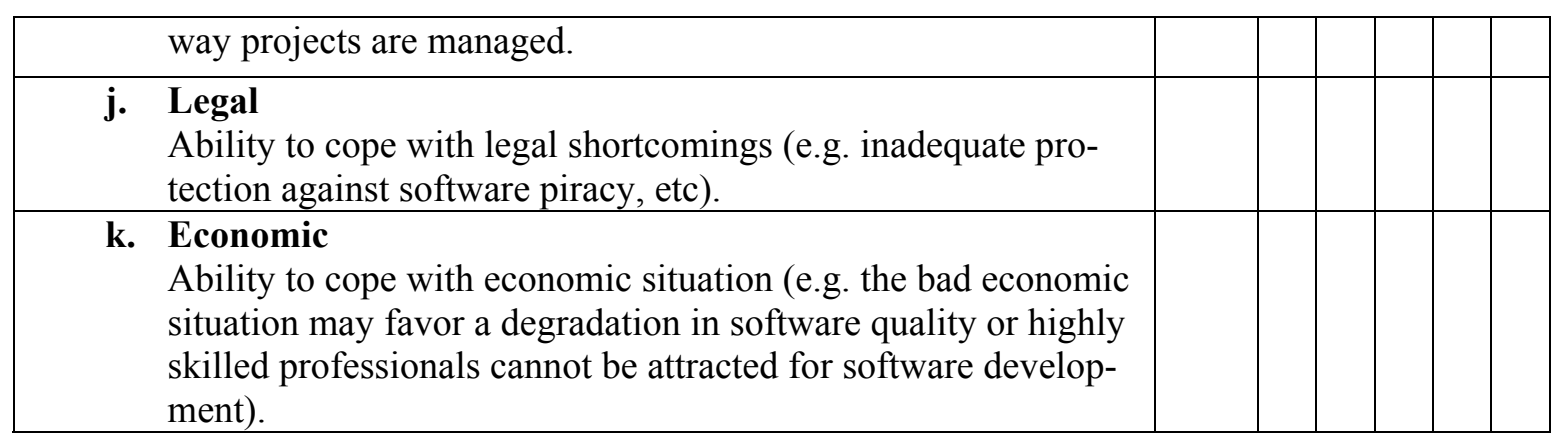

\section{Section C Project Success and Failure}

\section{Project success}

A successful project is a project that is delivered on time, within the budget, and on brief (in scope).

\section{Project failure}

A failed project is a project that is never completed or does not meet customer expectations.

\section{Project challenge}

A challenged project is a project that is completed, but is either late, over-budget, or does not meet all the requirements.

\begin{tabular}{|cl|l|}
\hline 1. & $\begin{array}{l}\text { Total number of projects completed in last } 12 \text { months by your } \\
\text { organization }\end{array}$ & \\
\hline $\mathbf{2 .}$ & Number of successful projects in last 12 months & \\
\hline 3. & Number of failed projects in last 12 months. & \\
\hline 4. & Number of challenged projects in last 12 months & \\
\hline
\end{tabular}

\section{Section D}

\section{General Information}

1. Total no. of staff in your organization (IT and non-IT)

\section{Optional information}

2. Name of company

3. Position of respondent

4. Would you like to receive an electronic copy of the survey results $\underline{\text { Yes/No }}$ (delete whichever is not applicable)

If yes, please provide your email/postal address 


\section{Biographies}

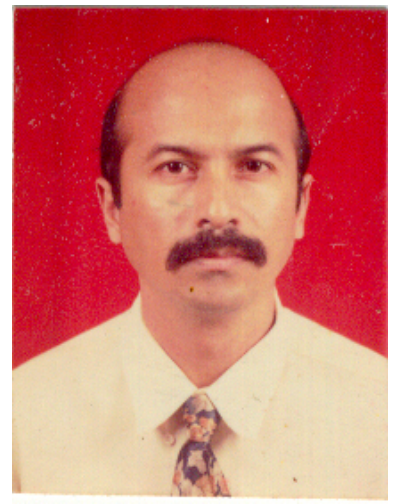

Aneerav Sukhoo, is a project manager working for the Ministry of Information Technology \& Telecommunications in Mauritius. He has 15 years of experience, out of which 8 years in IT project management, in dealing with implementation of IT projects in the Public Service.

He has a Honours Bachelor degree in computer Science from the University of South Africa and a Master of Information Technology degree from Charles Sturt University. He is presently preparing a $\mathrm{PhD}$ thesis at the University of South Africa for the development of a software project management methodology.

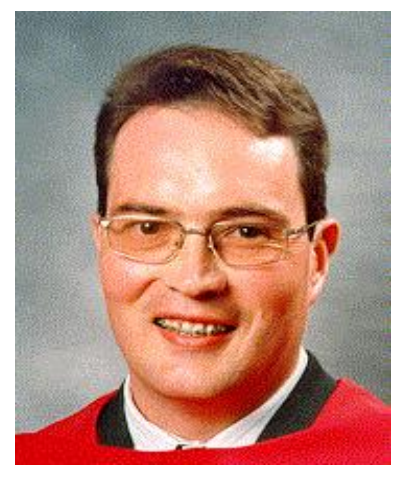

Andries Barnard, associate professor in the Department of Computer Science and Information Systems, holds a PhD (Computer Science). He teaches undergraduate courses in automata theory and formal languages and project management, as well as postgraduate courses in project management and research methodology. His research interests include computer ethics and graph grammar languages.

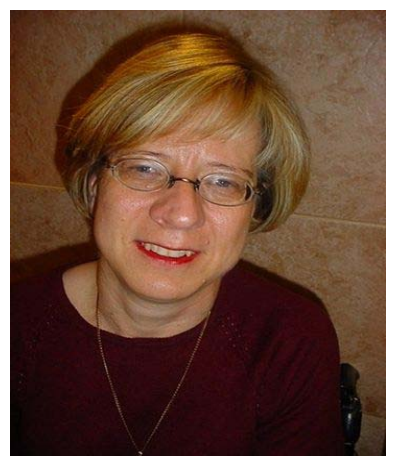

Mariki Eloff received a $\mathrm{PhD}$ Computer Science degree from the Rand Afrikaans University (RAU), South Africa. She has presented research papers at international and national conferences focusing on information security. She joined Unisa as an associate professor in the School of Computing during October 2002. She has assisted in the organization and management of international conferences in information security and has been part of the ISSA Conferences since its inception in 2000 .

During 2001 she participated in information security management research projects under the joint leadership of RAU and the South African Bureau of Standards (SABS). She has also been engaged in the development of various information security-training modules for industry.

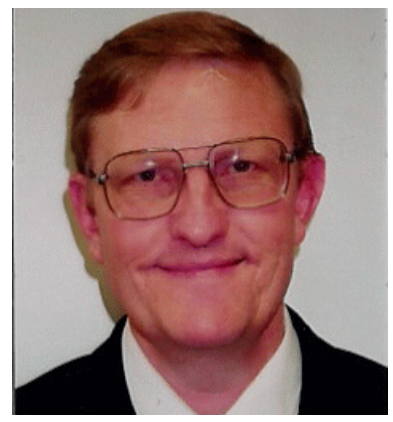

John A. Van der Poll is an associate professor and acting head of the Department of Systems Organisation in the School of Computing at the University of South Africa (UNISA). He holds a PhD in Computer Science and teaches an undergraduate course in operating systems, as well as postgraduate courses in compiler construction and formal program verification. His research interests are in formal specification languages and automated reasoning. 